\title{
Job Satisfaction, Organizational Commitment, and Turnover Intention of Online Teachers in the K-12 Setting
}

\author{
Ingle M. Larkin, Laurie Brantley-Dias, Anissa Lokey-Vega \\ Kennesaw State University
}

\begin{abstract}
The purpose of this study was to measure and explore factors influencing K-12 online teachers' job satisfaction, organizational commitment, and turnover intentions. Using Maslow's Hierarchy of Needs (1954), Herzberg's Two-Factor Theory of Satisfaction (1959, 1968), Meyer and Allen's measure of Organizational Commitment (1997), and Fishbein and Ajzen's Theory of Reasoned Action and Planned Behavior (1975), this mixed-methods study was conducted in public, private, charter, for-profit, and notfor-profit K-12 online schools in a single Southeastern state. The researchers used a sequential explanatory design by collecting and analyzing quantitative data and then qualitative data in two consecutive phases. Phase I included a 74-item survey with responses from 108 participants. Results revealed that K-12 online teachers have a moderate to high level of job satisfaction, which corresponds to their affective commitment to their organization and their intent to remain teaching in the online setting in the immediate, intermediate, and long-term future. Participants identified flexibility, meeting student needs, technical support, and their professional community as the most satisfying aspects of their jobs. Compensation, workload, missing face-to-face interaction with students, and unmotivated students were identified as least satisfying aspects of their work. In Phase II, eight qualitative focus group interviews were conducted and analyzed using constant comparative methods; these findings confirmed and illuminated quantitative results from Phase I. This study informs K-12 online school leaders, policymakers, and researchers of statistically significant variables that influence K-12 online teacher satisfaction, commitment, and retention.
\end{abstract}




\section{Introduction}

As more school districts and students move to online platforms for teaching and learning, various modes of online education have emerged, including state, local, private, and nonprofit, agencies. Each of these vary in the scope of subjects, grade levels, and delivery models (Archambault \& Crippen, 2009). Some virtual schools include a curriculum that is entirely online, while others offer a hybrid model of online and traditional instruction; still others provide specific distance education courses in addition to the traditional courses offered at a brick-and-mortar school (Roblery \& Marshall, 2003). With online student enrollment increasing each year, there is also an increasing demand for qualified online teachers to meet the growing needs of learners. However, the United States is continuously faced with the threat of teacher shortages, resulting from a combination of retiring teachers, increasing student enrollment, and teachers who leave to pursue other careers (AEE, 2014; Ingersoll, Merrill, \& Stuckey, 2014; Riley, 1999). New teachers leave the classroom to pursue other careers at a rate of $30-50 \%$ within three to five years of entering the field of education, and in some schools attrition outpaces retention (AEE, 2014; DarlingHammond, 2001; Dawson, 2001; Ewing \& Manuel, 2005; Ingersoll 2002; Ingersoll, Merrill, \& Stuckey, 2014). When considering the long-term trajectory of online learning, employing and retaining a critical body of K-12 online teachers has become a pressing concern. In order to maximize retention, studies are needed that investigate the satisfaction and commitment of K-12 online teachers and their intent to remain employed in the online setting.

\section{Problem}

With the continual growth of K-12 online schools, as well as students accessing online courses through their brick-and-mortar schools (Gemin, Pape, Vashaw, \& Watson, 2015), there is an urgent need to prepare and retain a skilled body of online teachers who can successfully engage learners in blended, hybrid, or fully online environments. Even with such growth in the practice of K-12 teaching and learning, the available and useful research to guide that practice has not kept pace with the need (Barbour, 2012). The number of online students is quickly outpacing the relative number of online teachers; with states passing legislation requiring students to complete online classes prior to receiving their diploma, the demand for online teachers will only escalate (Gemin et al., 2015). Given the lack of consistent state policy and teacher preparation requirements (Archambault \& Kennedy, 2014; Davis \& Roblyer, 2005; Watson, Pape, Murin, Gemin, \& Vashaw, 2014), and because there is limited research in the new field (Barbour, 2012; Barbour \& Reeves, 2008; ETS, 2011; Reeves, 2006), the task seems even more insurmountable when taking into consideration the historically high rates of teacher turnover, thereby raising concerns that the field of online education may experience the same teacher exodus that has plagued traditional, face-to-face schools (Darling-Hammond, 2003; Ingersoll, 2001; Ingersoll, Merrill, \& Stuckey, 2014). There is a critical need to determine the job satisfaction of K-12 online teachers and identify the factors that influence satisfaction or dissatisfaction as they relate to the teachers' intent to remain in the field of online teaching. In so doing, school leaders, institutions of higher education, policy makers, researchers, and practitioners can more carefully design and implement programs for online learning that prepare and retain high quality online teachers to meet the demands of $21^{\text {st }}$ century learners.

\section{Purpose}

Much literature exists concerning job satisfaction across many professions, including teacher job satisfaction, (Bolliger \& Wasilik, 2009; Chaney, 1991; Green, Alejandro, \& Brown, 2009; Hagedorn, 2000; Herzberg, 1966; Herzberg, Mausner, \& Snyderman, 1959; Perrachione, Petersen, \& Rosser, 2008; Sirin \& Sirin, 2013; Tett \& Meyer, 1993; Vroom, 1964; Weiss, Dawis, England, \& Lofquist, 1967). While there is a growing body of knowledge about K-12 online schools and students, there is a limited 
body of knowledge concerning K-12 online teachers (Allen \& Seaman, 2013; Archambault \& Crippen, 2009; Deubel, 2008; Fournier, 2013), and at the time of this study, the literature search did not reveal any research concerning K-12 online teachers' level of job satisfaction, commitment, or turnover intention. By contrast, research does exist about the job satisfaction of online instructors in higher education (Allen \& Seaman, 2013; Bolliger, Inan, \& Wasilik, 2014; Bolliger \& Wasilik, 2009; Green et al, 2009; McLawhon \& Cutright, 2011; Picciano, Seaman, \& Allen, 2010), and while this research highlights the benefits and challenges inherent to teaching online, it does not completely transfer to the realm of K-12 teaching, largely due to the different challenges of teaching K-12 learners versus adult learners, such as motivation, cognitive development, and self-directedness. The purpose of this study was to identify the level of job satisfaction among K-12 online teachers and identify the variables that influence their satisfaction and dissatisfaction, as well as measure participants' organizational commitment and intent to remain in the field of online education.

\section{Theoretical Framework}

This study was framed by a combination of the theories informing job satisfaction, organizational commitment, and turnover intention. Each theory is steeped in research throughout the twentieth century, providing seminal works through which the researchers built the foundation for this research study. The theories of job satisfaction, organizational commitment, and turnover intention have been paired together in research from various academic and professional fields, revealing insights into K-12 online teachers' satisfaction and commitment to the profession.

\section{Theory of Job Satisfaction}

Several theories contribute to the theoretical framework of job satisfaction. Job satisfaction is achieved when the job and its environment meet the needs of the individual (Maslow, 1954). Maslow organized these needs in a hierarchy, including physiological, social-emotional, safety, love and belongingness, esteem, and intellectual; however, intellectual needs cannot be met until all of the lower and most basic human needs are satisfied. Once the most basic level of need is satisfied, the needs on the next level become the priority. Only when one feels connected, safe, and a sense of belonging at their place of employment can the higher level needs, such as esteem and self-actualization be achieved.

Motivation can also play into the theory of job satisfaction because motivation is closely tied to personal and professional satisfaction (Maslow, 1954; Vroom, 1964). Blackburn and Lawrence (1995) combined Maslow and Vroom's work and asserted that most cognitive theories assume people's behavior results from the individual's perception of their capacity to respond and their perceived estimation of possible rewards and consequences; therefore, individual motivation is the balancing of self-efficacy, personality, and perceived rewards (McLawhon \& Cutright, 2011). Collectively, the theory of job satisfaction is dependent upon how closely a person's abilities match the requirements of the job and the degree to which the person's needs are met by reinforcing aspects of the work environment (Weiss, Dawis, Lofquist, \& England, 1966).

Herzberg, Mausner, and Snyderman (1959) categorized variables affecting a worker's job satisfaction into two factors: motivators and hygienes. Motivators are intrinsic factors, including such items as achievement, recognition, the work itself, responsibility, and advancement, while hygiene or extrinsic factors include pay, job security, work conditions, supervision, and interpersonal relationships. Herzberg et al. (1959) proposed that motivators produce job satisfaction, while hygienes may lead to job dissatisfaction. Herzberg et al. (1959) theorized that individuals are more motivated by intrinsic than extrinsic factors in their work, further explaining, "factors that lead to positive job attitudes do so because they satisfy the individual's need for self-actualization in his work" (p. 114). Herzberg (1968) found that five factors contribute to job satisfaction, including achievement, recognition, the work itself, 
responsibility, and advancement. Herzberg (1968) also identified eleven factors that, if inadequate, could lead to job dissatisfaction, including salary, growth potential, interpersonal relationships with subordinates, interpersonal relationships with peers, interpersonal relationships with superiors, status, supervision, company policy, working conditions, personal life, and job security.

\section{Organizational Commitment}

Organizational commitment is traditionally defined as "a strong belief in and acceptance of the organization's goals and values, a willingness to exert considerable effort on behalf of the organization, and a definite desire to maintain organizational membership" (Watson, 2010, p.18). Organizational commitment is thought to be an important part of the psychological condition of the employees, including the attitudes they generalize towards their organization (Sirin \& Sirin, 2013). Others define organizational commitment as the extent to which employees see themselves belonging to the organization (or parts of it) and feel attached to it (Meyer, Kam, Goldenberg \& Bremner, 2013; van Dick, 2001). Nagar (2012) asserted "organizational commitment is essential for retaining and attracting well qualified workers as only satisfied and committed workers are willing to continue their association with the organization and make considerable efforts towards achieving its goals" (p.43).

The most popular and widely used commitment construct, which the researchers applied to this study, was put forward by Meyer and Allen (1991) and postulates three components: affective, normative, and continuance commitment. Affective commitment expresses the emotional attachment of the employees to their organization, their desire to see the organization succeed in its goals, and a feeling of pride at being part of that organization (Allen \& Meyer, 1990; Cohen, 2003; Mowday, Steers \& Porter, 1979; Nagar, 2012; Meyer, Kam, Gildenberg \& Bremner, 2013; Porter, Crampon \& Smith, 1976). Those employees with a higher degree of emotional commitment are more likely to continue working for the organization voluntarily and eagerly because they feel integrated within the organization and internalize the norms and values of the organization as their own (Nagar, 2012). Normative commitment, by contrast, does not correspond to any individually felt attachment of the organization members, but rather reflects their moral or ethical obligation towards the organization because maintaining membership is viewed as "the right thing to do" (Meyer \& Allen, 1991; Nagar, 2012; Wiener, 1982). Wiener and Gechman (1977) suggested that normative commitment manifests from the socialization and induction process of newcomers to the organization so that the individual is "indebted to his organization for having invested its time and resources on him and feels responsible to repay for the benefits that he gets from the organization by putting effort on the job and staying on the job" (Nagar, 2012, p. 48). Continuance commitment refers to the individual's perceived need to continue with the organization because, when weighing the pros and cons, leaving the organization would be costly. Those employees with continuance commitment find it difficult to give up membership to their organization due to the fear of the unknown, such as having few or no appealing professional alternatives, and therefore remain with their organization because they feel they must stay (Meyer, Allen, \& Smith, 1993).

\section{Turnover Intention}

According to Fishbein and Ajzen, "the best single predictor of an individual's behavior will be a measure of the intention to perform that behaviour" (1975, p. 369). Empirical evidence supports the position that an employee's intent to stay or leave is strongly and consistently related to voluntary turnover (Dalessio, Silverman \& Shuck, 1986; Mathieu \& Zajac, 1990). Intention to stay is defined as employees' intention to continue in the present employment relationship with their current employer on a long-term basis. Inversely, Vandenberg and Nelson (1999) defined employees' intention to quit as an individual's estimated probability that they are permanently leaving their organization at some point in the near future. Intention to stay mirrors an individual's level of commitment to his organization and their willingness to remain employed (Hewitt, 2004). Several research studies have suggested that the concept of intention is the most important determinant of actual turnover (Igharia \& Greenhaus, 1992; Tett \& Meyer, 1993). As depicted in Figure 1, when individuals are committed to an organization, their intent to 
remain with the organization and work towards the organization's goals is high (Mowday, Porter, \& Steers, 1982). Conversely, if commitment to the organization is low, the employee's intention to leave is high (Mowday et al., 1982). Dalessio et al. (1986) proposed that more emphasis and concern should be given to employee's intention to stay (retention) rather than intention to leave (attrition), as whenever an employee does exit, an organization incurs the cost of recruiting, training, and retaining another employee.

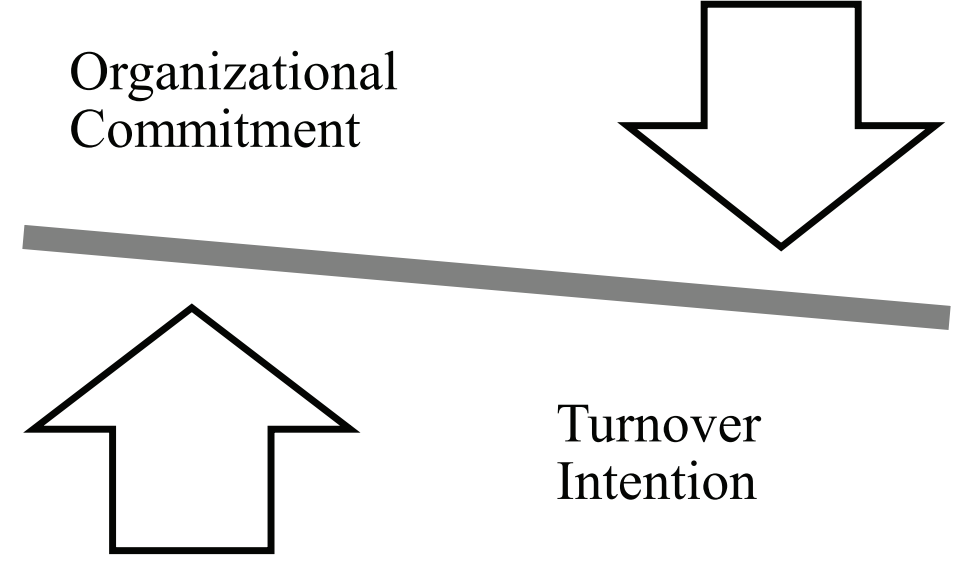

Figure 1. Inverse Relationship of Commitment and Turnover Intention

\section{Convergence of Theories}

This study was grounded in two prominent academic theories: Theory of Job Satisfaction and Theory of Organizational Commitment. These dual lenses served as the conceptual foundation to frame the discussion of K-12 online teacher job satisfaction and organizational commitment as it relates to their intent to remain teaching in this particular setting. The theory of job satisfaction provided the psychological foundation to explain internal motivation and external demotivation with regard to how employees view their job based on their individual needs and expectations, and the organization's ability to satisfy those needs. The theory of organizational commitment provided a model to explain how and why people decide whether to leave or remain in their current position of employment, which is tied to their level of job satisfaction. Therefore, the researchers proposed that job satisfaction and organizational commitment have a reciprocal relationship and are the antecedents of the formation of individual's turnover intentions (Figure 2).

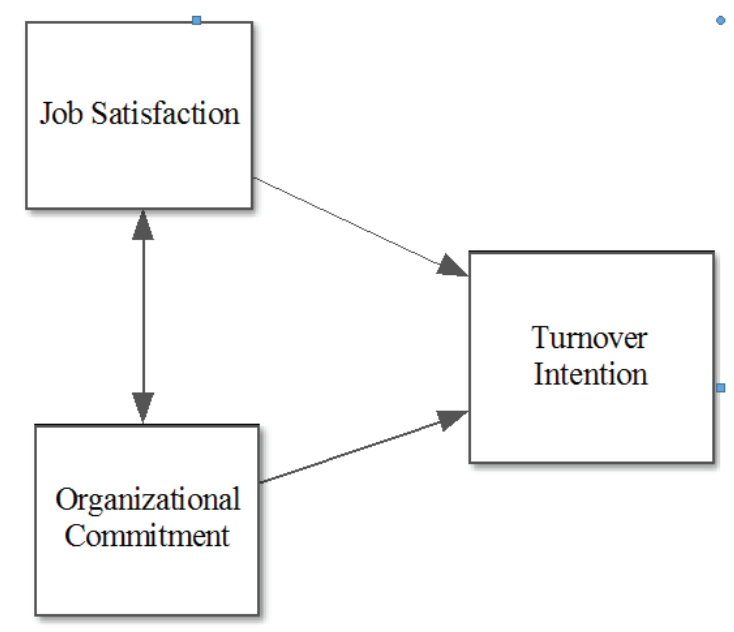

Figure 2. Convergence of Theoretical Frameworks 
The combined review of literature and the theoretical framework informed the development of the following guiding questions used in this investigation:

1. What is the level of job satisfaction among K-12 online teachers?

2. What is the level of organizational commitment among $\mathrm{K}-12$ online teachers?

3. What is the turnover intention of $\mathrm{K}-12$ online teachers?

4. What do online teachers perceive as barriers or pathways to retention?

The first three research questions each generated a test hypothesis, while the fourth research question generated qualitative data to enhance the understanding of the quantitative results.

\section{Methods}

The researchers employed a sequential explanatory mixed methods design (Figure 3) by collecting and analyzing quantitative (QUAN) data and then qualitative (qual) data in two consecutive phases within this study (Johnson, Onwuegbuzie, \& Turner, 2007).

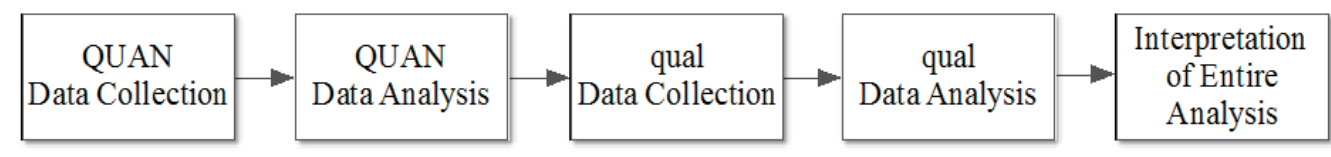

Figure 3. Sequential Explanatory Design (Creswell, 2009)

\section{Participant Selection}

For the first phase of the study, we used nonprobability convenience sampling to recruit participants from 11 K-12 online schools in the southeastern United States. Online school administrators were solicited by email asking them to invite their full-time and part-time online teaching faculty to participate in the study by forwarding their teachers an email containing a URL survey link for Phase I of the study. All participants were provided with a URL linked copy of the Informed Consent document and were required to electronically consent to participate prior to proceeding with the survey.

Participants $(\mathrm{n}=108)$ in the study were teachers employed full-time or part-time in either forprofit or nonprofit K-12 online schools, which included public, state-run, charter and private. Of the 108 participants, $75 \%$ were female and $25 \%$ were male. The majority ranged from 25-54 years of age, and $81.9 \%$ of participants reported having a Masters degree or higher. Teaching experience was reported in years according to type: face-to-face $(\mathrm{M}=11.27)$, blended or hybrid $(\mathrm{M}=.62)$, and fully online $(\mathrm{M}=3.08)$. More than $66 \%$ of the participants reported working at a state-affiliated online school (public, charter, district or state-level). Survey participants were predominately high school teachers, with the frequency descending steadily from high school, to middle school, to elementary school. The overwhelming majority of online courses taught by the teachers were the four core academic subject areas: History/Social Studies (22\%), Language Arts (20\%), Math (26\%), and Science (25\%). Other academic areas, such as Foreign Language, Physical Education, or elective courses, represented roughly 2-9\% all other courses taught by K-12 online teacher participants.

All participants had the option of indicating an interest in participating in the second phase of the study. From the 43 who volunteered, a representative sample $(n=8)$ was selected based on gender, school 
type, employment status, grade and subject areas taught, turnover intentions, and overall satisfaction with teaching online. Of the participants, one was male and seven were female. Five were employed full-time, two were employed part-time, and one was employed both full- and part-time at two different online schools.

\section{Phase I Data Collection}

The primary method for the quantitative data collection phase was a cross-sectional survey design. The first phase of data collection employed the first author's researcher-constructed instrument called Job Satisfaction and Commitment of Online Teachers (JSCOT). The JSCOT was assembled from components of several existing instruments but borrowing most heavily, with permission, from the Online Faculty Satisfaction Survey (OFSS) (Bolliger \& Wasilik, 2009), the Online Instructor Satisfaction Measure (OISM) (Bolliger et al., 2014) and the Organizational Commitment Questionnaire (OCQ) developed by Meyer and Allen (1991; 1997). The survey was administered online using Google Forms and remained open for 12 weeks.

The JSCOT survey instrument consisted of 21 demographic questions, 28 closed-response research items with a five-point Likert scale, 1-strongly disagree to 5-strongly agree, to measure job satisfaction, and two open-response questions. In an effort to control for researcher bias, the open response fields for Items 29 and 30 invited participants to describe variables and experiences they perceived as the most and least satisfying components of online teaching. In addition to the job satisfaction survey items, the unmodified 18-item Organizational Commitment Questionnaire (OCQ) (Meyer \& Allen, 1991; 1997) was embedded into the JSCOT survey instrument. The OCQ is a selfscoring questionnaire with a 5-point Likert scale.

The final component of the JSCOT survey measured K-12 online teachers' turnover intentions. The measure of turnover intention is considered a predictive model believed to be a strong indicator of actual turnover (Bluedorn, 1982; Chacon, Vecina, \& Davila, 2007; Fishbein and Ajzen, 1975; Lee \& Mowday, 1987; Perrachione, Petersen, \& Rosser, 2008; Sirin \& Sirin, 2013). This portion of the survey included five intention items that assessed online teachers' intent to remain or depart from their organization in the immediate, intermediate, and long-term future. Turnover intention is traditionally measured using a dichotomous scale; for each intention item, participants chose Yes (1) or No (0) to indicate the agreement with questions in regards to their immediate and long-term intentions to remain in the field of K-12 online teaching.

To ensure content validity, a team of eight non-participating online teachers piloted the survey questions; based on the pilot team's experience and feedback, the instrument was modified until the questions were finalized. The instrument was reviewed by field experts on an ongoing basis, including professional colleagues in the field of K-12 online teaching and learning, professors and practitioners of educational research.

Survey items addressing job satisfaction were logically grouped into five different scales: Student Interaction satisfaction, Affordances satisfaction, Institutional Support satisfaction, Courseware and Instruction satisfaction, and Overall Satisfaction. Of the five scales, four fit into balanced categories while one scale, Overall Satisfaction, was made up of fewer questions that sought to directly measure participants' job satisfaction. Survey items addressing organizational commitment were grouped by the existing three commitment scales (Meyer and Allen, 1991; 1997): Affective commitment, Normative

commitment, and Continuance commitment. A representative sample item is provided for each of the eight scales in Table 1. 
Table 1: Survey Scales and Representative Items

Scale

Student Interaction

Affordances

Institutional Support

Courseware

Instruction

Overall Satisfaction

Affective

Normative

Continuance

\section{Representative Item}

My interactions with online students are satisfying.

I am satisfied with the convenience of the online teaching environment.

I have adequate technical support from my institution.

and I am satisfied with the quality of the content of the online courses I teach.

I am satisfied with my position as an online teacher.

This organization has a great deal of personal meaning for me.

This organization deserves my loyalty.

I feel that I have too few options to consider leaving this organization.

Reliability of the survey scales was established using internal consistency reliability indexes (Cronbach, 1951). The Institutional Support scale produced the lowest reliability (.51), suggesting that the items included on that scale are not measuring the same construct and thus must be reevaluated for future studies. Table 2 presents the reliability of each survey scale and lists the corresponding survey items.

Table 2: Reliability of Scales

Factor Scales

Survey Item

Cronbach's $\alpha$

Student Interaction

$1,3,7,10,18,23$

0.75

Affordance

$2,8,11,19,20,24$

0.65

Institutional Support

$5,13,15,16,21,22,26$

0.51

Courseware and Instruction

$4,6,9,12,14,25$

0.63

Overall Satisfaction

$17,27,28$

0.66

Affective

$1,2,3,4,5,6$

0.87

Normative

$13,14,15,16,17,18$

0.81

Continuance

$7,8,9,10,11,12$

0.74 


\section{Phase I Data Analysis}

During the quantitative survey phase of the study, participants selected responses on a five-point Likert continuum, where three served as the midpoint of the continuum and signified a neutral position. Any score above three shows a positive association with a particular question, idea, or concept related to job satisfaction or organizational commitment. Any score below three indicates a weak or negative association with a particular question, idea, or concept related to job satisfaction or organizational commitment. Survey items that focused on hygiene were worded negatively and consequently were reverse scored to ensure that all data regarding satisfaction or dissatisfaction could be accurately interpreted.

To assess the level of job satisfaction and organization commitment, the JSCOT survey response options were assigned a weighted score with Strongly Disagree having a value of one and Strongly Agree having a value of five. The quantitative survey instrument yielded a total of 28 scores that were averaged to form an overall measure of job satisfaction. Teachers who had a high score were very satisfied (maximum score of $5 \times 28$ questions $=140$ ) while teachers with a low score were very dissatisfied (minimum score of $1 \times 28$ questions $=28$ ) with their jobs. For the ease of interpretation, all scale scores were converted to a percentile ranging from 0 to $100 \%$ to represent K-12 online teachers' level of job satisfaction or dissatisfaction using the scoring guidelines of the Minnesota Satisfaction Questionnaire (MSQ) (Weiss et al., 1967) for general job satisfaction (Figure 4). The percentile score range of 26-74 indicates average job satisfaction; within that continuum, higher scores are associated with higher levels of satisfaction. A percentile score of 75 or higher indicates a high degree of satisfaction (very satisfied or strongly agree), and a percentile score of 25 or lower represents a low level of satisfaction (very dissatisfied or strongly disagree).

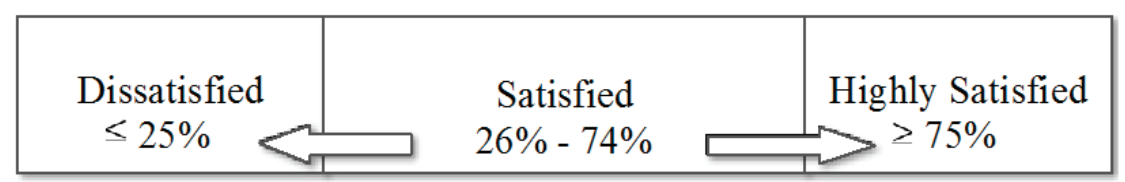

Figure 4. MSQ Satisfaction Scale

The Organizational Commitment Questionnaire (OCQ) portion of the survey instrument employed a 5-point Likert scale with anchors ranging from 1-strongly disagree to 5-strongly agree. The results of the 18 items were summed and divided by 18 to arrive at a mean Likert score that serves as an indicator of an employee's organizational commitment. Four items are negatively phrased and were reverse scored to reduce response bias (Vogt, 2007). The higher an individual's score, the higher their level of commitment to the organization (Sirin \& Sirin, 2013).

The two open-response items generated 26-pages of participant response data. This document was loaded into ATLAS.ti and coded using line-by-line descriptive coding techniques (Saldana, 2013). The researchers tallied the number of times a particular concept was communicated by participants and compiled a list of the five most frequently identified satisfying and dissatisfying aspects of teaching online. The researchers used a separate codebook in Phase I and II of the study due to differences in the types of questions asked of participants, though the codes generated in each phase were largely similar. 


\section{Phase II Data Collection}

In the second phase of data collection, the first author conducted a synchronous online focus group to explore survey findings related to K-12 online teacher satisfaction, commitment, and turnover intention. In keeping with the sequential explanatory design, where the qualitative data is used to expound upon the quantitative findings, the researchers created semi-structured, open-response interview questions based on survey findings that warranted further probing. Additionally, by framing each interview question with group data from Phase I and allowing participants to discuss their own experiences or interpretation of the data, the researchers avoided presenting participants with leading questions (Merriam, 2009).

Six participants attended a synchronous focus group session; additionally, two participants who originally agreed to participate in the focus group, but were unable to attend due to last minute schedule conflicts, participated asynchronously by submitting written responses to the focus group questions. In total, focus group responses were analyzed from eight participants. Each focus group session included a balance of different school governance types to provide a rich and representative sample. A pseudonym was assigned to each participant to ensure privacy (Bridgette, Jane, Leah, Martha, Mary, Richard, Rita, and Veronica).

\section{Phase II Data Analysis}

The audio-recorded focus group was transcribed and then imported into the software system ATLAS.ti. The data were analyzed using a constant comparative method (Merriam, 2009). The initial open coding process generated 52 codes, which were then defined in a codebook. The researchers used the codebook to re-read the transcripts and further scrutinize the initial open coding, subsuming or relabeling text codes where appropriate. In the second cycle of coding, axial coding was implemented to find the codes that were dominant and remove redundant codes (Merriam, 2009; Saldana, 2013), of which 8 codes were collapsed, leaving 44 codes. During this process, the researchers looked for patterns of shared characteristics among the codes and grouped similarly coded data into 6 categories, also known as "families." From the six categories, three themes surfaced. Data from two themes helped to answer the research questions presented in this manuscript. The third theme addressed a subset of the research questions discussed in another publication (see Larkin, 2015). The coding process, including data sources, is detailed in Figure 5.

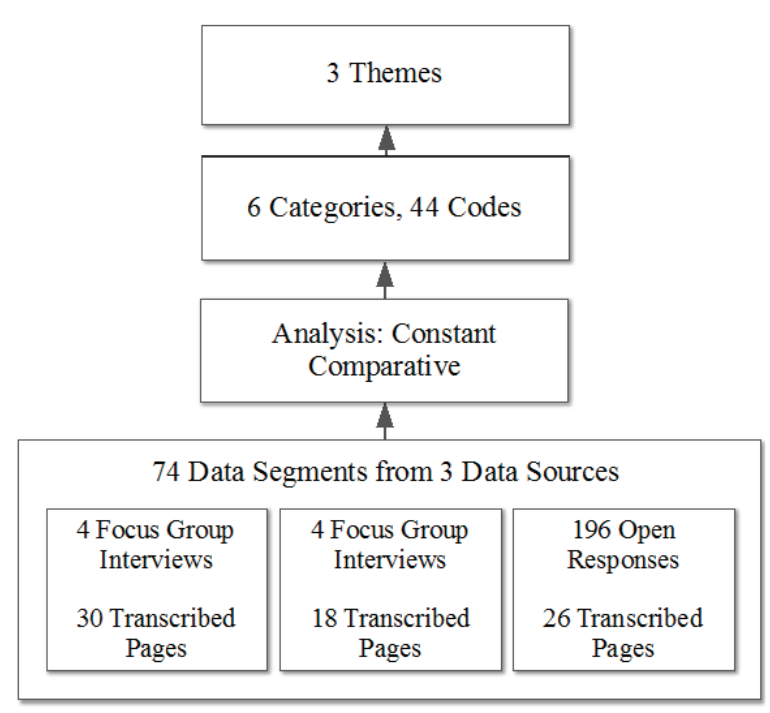

Figure 5. Codification Process 


\section{Phase I Results}

Based on the theoretical framework and the empirical literature on job satisfaction, organizational commitment, and turnover intention, three hypotheses were tested to answer three of the research questions.

H1. K-12 online teachers will report moderately high levels of job satisfaction. $H_{0}: \mu \leq 3, H_{A}: \mu>3$, where $\mu$ is equal to the mean score of all 28 5-point Likert scale items related to job satisfaction.

The first test hypothesis addressed participants' level of job satisfaction or dissatisfaction stating that K-12 online teachers will report moderately high levels of job satisfaction as measured by the Minnesota Satisfaction Questionnaire (MSQ) scale of satisfaction. The number three was used as a critical value for job satisfaction, as three is a midpoint on a 5-point Likert continuum and is considered average satisfaction. Any number less than three is associated with dissatisfaction, while a number greater than three is associated with higher levels of satisfaction.

Overall, K-12 online teachers reported a mean satisfaction of 3.69 on a 5-point Likert continuum. The corresponding average total satisfaction score is 103.6 out of 140 possible points, which corresponds to $74 \%$ satisfaction; data proved to be statistically significant with $\mathrm{p}<0.001$ for overall job satisfaction. As benchmarked by the MSQ guidelines, southeastern K-12 online teachers exhibited moderate to high levels of overall job satisfaction, and the first null hypothesis was rejected. The survey divided job satisfaction into five areas of satisfaction including student interactions, affordance (i.e., convenience), institutional support, courseware and instruction, and overall satisfaction (see Table 3).

Table 3: Average Job Satisfaction by Scale

\begin{tabular}{lcccc} 
Satisfaction Scale & $\mathrm{n}$ & Likert Mean Score & SD & $p$ \\
Student Interactions & 105 & 3.14 & 4.04 & 0.362 \\
Affordance & 104 & 4.40 & 2.69 & $<0.001$ \\
Institutional Support & 100 & 3.85 & 3.59 & 0.010 \\
Courseware and Instruction & 108 & 3.26 & 3.81 & 0.240 \\
Overall Satisfaction & 106 & 3.83 & 2.38 & $<0.001$ \\
\hline
\end{tabular}

Table 3 displays the Likert mean score for the job satisfaction scales. Of the five mean scale scores and the converted satisfaction percentages, Student Interaction produced the lowest satisfaction score of $62.83 \%$. Following student interaction, Courseware and Instruction indicated teachers were moderately satisfied at a score of $65.23 \%$. Teachers were highly satisfied with Affordances $(88.06 \%)$, Institutional Support (77.17\%), and Overall Satisfaction (76.6\%), as indicated by the MSQ scores exceeding $75 \%$.

H2. K-12 online teachers will report moderately high levels of affective and normative commitment, and low levels of continuance commitment. $\mathrm{H}_{0}: \mu \leq 3, \mathrm{H}_{\mathrm{A}}: \mu>3$, where $\mu$ is equal to the mean score of all 18 5-point Likert scale items related to organizational commitment.

The second test hypothesis addressed research question two and states that K-12 online teachers will report high levels of affective and normative commitment, and low levels of continuance commitment as measured by the Organizational Commitment Questionnaire (OCQ). Again, the number three was used as a critical value for organizational commitment, as three is a midpoint on a 5-point Likert continuum and is considered average commitment. Any number less than three is associated with lower levels of organization commitment, while a number greater than three is associated with higher levels of organizational commitment. 
The Affective commitment scale produced the highest mean score of 23.05 points out of 30 possible points for 6 items, or an average of 3.84 points on a 5-point Likert continuum, as noted in Table 4. The Normative commitment scale produced a mean score of 20.37 points, and the Continuance commitment scale produced the lowest mean score of 16.75 points out of 30 possible points.

Table 4: Average Organizational Commitment by scale

\begin{tabular}{lcccc} 
Commitment Scale & $\mathrm{n}$ & $\begin{array}{c}\text { Likert Mean } \\
\text { Score }\end{array}$ & SD & $p$ \\
Affective & \multicolumn{5}{c}{} & 3.84 & 4.25 & $<0.001$ \\
Normative & 106 & 3.39 & 4.17 & $<0.001$ \\
Continuance & 106 & 2.79 & 4.47 & $<0.0024$ \\
\hline
\end{tabular}

This outcome suggests that K-12 online teachers are committed to continuing employment at their organization because they internalize the ideals and mission of their online school, rather than staying because they lack professional alternatives or opportunities at present. Since participants scored highly on the affective and normative scales and low on the continuance scale, all at statistically significant levels $(p<0.05)$, the null hypothesis was rejected.

H3. K-12 online teachers will report low levels of turnover intentions. $H_{0}: p \geq 0.3, H_{A}: p<0.3$, where is $p$ is the proportion of participants who intend to leave, as measured by five turnover items.

The third test hypothesis addressed the third research question and states that K-12 online teachers will report low levels of turnover intentions as measured using a five-item incremental turnover timeline (Table 5). The researchers selected $30 \%$ or .30 as the critical value for turnover intentions because $30 \%$ is the historical rate of attrition for traditional K-12 teachers (AEE, 2014; DarlingHammond, 2001; Dawson, 2001; Ewing \& Manuel, 2005; Ingersoll 2002; Ingersoll, Merrill, \& Stuckey, 2014). When asked if they intended to continue teaching online in the immediate future, $95 \%$ responded Yes; however, teacher's intent to remain teaching online drops by approximately $20 \%$ over the career timeline presented. Additionally, roughly one-third of online teachers agreed that they would leave their job should a better opportunity arise.

Table 5: Turnover Intention Item Percentages

\begin{tabular}{lcc} 
Item & Yes & No \\
I intend to keep teaching online. & $95 \%$ & $5 \%$ \\
It is likely I will search for a new job in the next year. & $18 \%$ & $82 \%$ \\
In five years, I see myself still teaching online. & $81 \%$ & $19 \%$ \\
I will teach online only until a better opportunity arises. & $33 \%$ & $67 \%$ \\
I would like to remain teaching online for the remainder of my career. & $77 \%$ & $23 \%$ \\
\hline
\end{tabular}

For the 1-year (z-statistic $=-2.65, p=0.004)$ and the 5 -year $($ z-statistic $=-2.45, p=0.007)$ turnover intentions, the population proportion intending to leave online teaching is less than the critical value of $0.3(30 \%)$, leading the researchers to reject the null hypothesis. The projected attrition of online teacher participants $(19 \%)$ is less than the actual attrition of traditional teachers, which typically ranges from $30 \%$ to $50 \%$ within the first five years of teaching (AEE, 2014; Darling-Hammond, 2001; Dawson, 2001; Ewing \& Manuel, 2005; Ingersoll 2002; Ingersoll, Merrill, \& Stuckey, 2014).

In the case of the career-long turnover intentions (z-statistic $=-1.61, p=0.054$ ), the researchers failed to reject the null hypothesis. The p-value is close to 0.05 and while the result is not statistically significant, it is certainly indicative of a general intent to remain. It is worth noting, as the z-statistic values get closer to zero, the sample proportions intending to leave gets closer to 0.3 . This may be an 
indication of participants' uncertainty about the long-term future and not necessarily about an increasing intention to leave as time passes.

\section{Phase II Findings}

\section{Barriers to Retention}

Barriers to retention addressed the attrition of $\mathrm{K}-12$ online teachers and emerged from the categories institutional factors and student concerns. Institutional factors reflect aspects of the job that participants find particularly frustrating or dissatisfying, and therefore, present a risk to online teacher turnover. Among the institutional factors online teachers found most discouraging were compensation and income growth potential, physical demands, working summers, and the teacher evaluation system. In their own voices, participants also reflected on the issues they see as influencing turnover in their own schools. Student concerns also emerged as a category that leads to frustration among K-12 online teachers. The focus group participants identified concerns with inactive or truant students, student motivation and work ethic, at-risk or historically unsuccessful students, lack of parental support, student access to technology, and difficulty building relationships with online students.

\section{Institutional Factors}

Compensation and income growth potential. Focus groups participants reported being paid significantly less than their traditional classroom counterparts, taking $\$ 10,000-\$ 15,000$ pay cuts to teach online. Mary revealed, "There's a lot of people that work part-time along with their full-time teaching job." While most full-time online teachers were offered a regular salary, part-time teachers were often paid per student. This becomes problematic because part-time teachers are only paid once or twice a semester, depending on how many students enrolled, dropped, or completed the teacher's course throughout the semester. In addition to only being paid quarterly, the fluctuation in student enrollment from semester to semester made it very hard for online teachers who were paid per student to plan and follow a personal budget. When considering that most online teachers make less than traditional classroom teachers, plus work year-round, the disparity in their salaries becomes more apparent. Jane asserted, "I should be paid more considering that I am year-round. I would like for our salaries to reflect the $2 \frac{1}{2}$ to 3 months that we have also taken on, or summers should be optional and separate pay."

In addition to grievances of low compensation, teachers also discussed the limited income growth potential as a major reason to not remain teaching online long-term. Leah stated, "There is no growth in salary, limited opportunity to move up." Of his for-profit employer, Richard lamented:

In the corporate mindset, yes, there are small raises that happen every so often within your job, but primarily the big raises happen when you receive a promotion. If you're a teacher there is no promotion. You are a teacher. You're going to continue being a teacher for a number of years. Since I have not received a raise in two years I've taken a de facto pay cut. There is an inflation rate. The buying power of what I was receiving two years ago is not the same as what I'm receiving today. That is a real issue.

Physical demands. Teaching online, often from the comfort of home, does not suggest it will be a physically demanding job, yet participants revealed it is more physically taxing than they expected. Mary communicated common false expectations of teaching from home, "People don't think that it's a lot. They think 'Oh, I'm going to lay on the couch and do my work.' It's really not like that." As with traditional teaching, online teacher participants reported not using the bathroom as often as they should or taking an adequate lunch break. But unlike traditional teaching, online teachers complained of vision strain, carpel tunnel syndrome from working at their computers, and rather than being on their feet all day, they are sitting all day. 
Teacher evaluation. While not mentioned as a dissatisfying aspect of the job, there was concern over how online teachers received their performance evaluation, particularly as many states consider performance-based pay for teachers. Teachers working for publically funded online schools were evaluated using the same criteria as other traditional teachers in their state, yet there is a large disconnect between the roles and responsibilities of online verses traditional classroom teachers, of which Mary exclaimed, "That's almost like putting a square peg in a round hole. We do a lot of the same things in theory, but we don't do them the same way. How do you compare that?" Mary recently ventured to a meeting hosted by her state's Department of Education concerning the teacher evaluation system and described what she learned:

I was the only one in the room that was an online teacher. I finally went up to them and asked, "Okay, how does this work for us?" They said, "Oh, this absolutely was not meant for online teachers."

Turnover. Focus group participants were asked why they believed online teachers leave the virtual classroom, particularly before five years. Mary spoke to the demands placed on teachers and asserted, "I think it's because of that expectation of you to have 500 kids. You need to call them all in six weeks. Really? How is that humanly possible? You start going, 'Oh, no. I can't do this job well enough."” Other teachers pointed to the inequality in pay as the reason online teachers will eventually head back to brick-and-mortar classrooms. Jane recommended, "To retain teachers past 5 years, I suggest paying according to the state salary schedule." Richard acknowledged, "The salary structure and the step system is very attractive for teachers and the benefits packages, particularly the retirement plan. It's very hard for any non-traditional school to match what the public schools can offer." Veronica considered a lack of new teacher support or training to be the number one culprit of online teacher attrition:

It is absolutely overwhelming to somebody doing it for the first time, just like with a new teacher walking into a face-to-face classroom. What they taught them in the School of Education is not reality. You need somebody there to mentor you and help you through until you kind of get your feet wet and kind of know that you are steady on them and can move forward. That's what's going to help retain them. Then making sure that the teacher is recognized for their contribution either because you're giving them raises or giving them new opportunities to do things. I think that's going to be the key to keeping the online teacher.

\section{Student Concerns}

Student motivation and inactivity. As focus group participants described the motivation and work ethic of their students, there seemed to be two polar student profiles: students who were highly motivated and accelerating their education, and students who were unmotivated and trying to recover course credit. Of the more successful students, Richard suggested, "there are some students that this environment is perfect for them. They do very well in the online environment. They're highly motivated and can work. They like the ability to take more classes and get done more quickly." Veronica countered, "I do not think that online education is for every single student. Some really struggle with it. Some, like I said, procrastinate, and some will procrastinate too much, to the point that you can't even get them going." Richard posited, "It is a problem with motivation, but you have that same problem in a brick and mortar school." Most of the participants described what could be considered students' bare minimum approach to work and revealed there are a number of students on their roster that have never logged in or attempted any work, and who would most likely fail their class that semester.

Students at-risk. Richard explained that many of his students did not perform well in traditional public schools, and subsequently did not perform well in the online environment for the same reasons they were unsuccessful in the traditional setting, claiming, "They aren't motivated. They're having 
difficulty. We do have a problem with truancy." Mary agreed that the same problems that plagued many students in traditional classrooms follow them into the online realm. Mary continued:

I think there are students that ask to be moved to an online school, and then there are students who are forced to move to an online school. The ones who are forced usually are not that great at accomplishing anything. There are usually many other issues besides actually learning. Parents don't know anything; teachers don't know anything... I don't know how you fix that. You have to go way back in time.

Rita, who works predominantly with at-risk students, conveyed that she was very concerned with the course content because the reading level of the curriculum was too high while the cultural relevancy was too low. She explained that it is up to the teacher to fill in those gaps and make the curriculum more tangible and relevant to at-risk students. Specifically, for the students who were older or who have had little academic success in the past, Rita emphasized, "I also think the connection to real life and career is another factor in increasing student engagement."

Parental support. Parental support was a major concern for online teachers. Because online teachers are not physically present to monitor students, they must rely on the parents to oversee their child's progress throughout the day. Most schools emphasized to families enrolling in their school that they were making a triad agreement between the teacher, student, and parent. Mary stressed that online students need constant support at home and that while she can offer support from the school's end, "I can't go there and sit next to them and put their fingers on the keyboard."

Student access to technology. Student access to technology is among the frustrations online teachers experience, despite policies requiring families to sign a technology understanding and access agreement when enrolling in an online school. Richard expounded, "We have a lot of problems with technical ignorance, which is humorous, considering it's an online school and you've got students who don't know how to deal with computers." A few teachers described situations where the students did not have a computer, or perhaps did not have Internet connectivity at home, as illustrated by Richard as he relayed conversations he has had with students in the past:

They come to us and we say, "Why haven't you started your lessons?" "Well, I don't have a computer." Or, "I have a computer, but we don't have Internet access." Or, they come back and tell us, "Well, I'm trying to do the work on my phone." It's not going to work that way. You're not going to be able to do your work on your phone. You need to actually have a computer that's going to do this.

Some online schools provide students with a computer when they sign up for online classes, but with any privilege, this can be abused. Richard communicated that particularly when students enrolled, but never attended a class or submitted an assignment, his school was "afraid that they registered with us simply because under their government program they could get a free computer to work with." Participants recounted instances when families provided the wrong address, or claimed their computer never arrived and were sent second computer. Unfortunately, the missing computers were hard to retrieve, with both Richard and Mary reporting their schools have traced computers to pawn shops and eBay.

Student relationships. While not the most mentioned dissatisfying aspect of online teaching, some participants stated they would like to get to know their students better, or have more direct contact with them. The two largest barriers participants saw were the large number of students they teach and the geographic distance that separates them. Referencing her time spent teaching in a traditional school, Jane stated, "I also miss the time with students... I think that there should be time set aside for this as a scheduled meeting. We would need less students to gain this time." Leah expressed that other time- 
consuming duties, such as logging data points and contact logs, or grading, could be automated and leave time to interact with students in more meaningful ways.

\section{Pathways to Retention}

Pathways to retention addressed retaining K-12 online teachers and emerged from the categories of encouraging factors and support network. Encouraging factors reflects aspects of the job that participants found particularly enjoyable or gratifying, and therefore, when present on the job, were more likely to encourage online teacher retention. Among the factors online teachers found most encouraging were the ability to meet a variety of student needs, effective technology and courseware, design opportunities, room for teacher individuality and creativity, and the flexibility to teach on a schedule that is not bound by time or geographic location. Having a support network also proved to be key to the satisfaction and retention of the K-12 online teacher participants. The focus group participants identified many forms of support, including the school's leadership, timely assistance, collaboration with other teachers, recognition for their accomplishments, and professional development opportunities.

\section{Encouraging Factors}

Flexibility. The participants valued the flexibility the job afforded them and their students. They noted not only the convenience of being able to teach at any time and from any location, but also the variety of resources they can incorporate into their instruction. Richard affirmed, "I enjoy the flexibility to be able to do my job wherever and whenever I need to. As long as I have a wireless connection I can go on."

Less stress. Another encouraging factor cited by participants is a reduced level of stress. Despite taking $\$ 15,000$ pay cut from her salary as a traditional classroom teacher, Rita explained, "The trade-off for me is I like what I am doing and I am not stressed like I used to be." Almost all participants noted a lack of student discipline issues as a large incentive for remaining in the online classroom. Richard, who confessed to struggling with classroom management in the past, claimed, "One thing that I always joke about is if I have a problem with kids talking in my class I can hit the mute button, and then I don't have to worry about them talking in my class." Mary asserted, "It's definitely less stress to deal with classroom management issues. I get more actual teaching done in one live lesson than I do in two weeks in the traditional classroom, basically because of behavior."

Student needs. Fulfilling a variety of student needs was another concept focus group participants identified as satisfying. Diverse student needs may include students with special ability-based learning needs, the students' life circumstances, such as their physical and emotional health, a need for advanced courses, or hobbies that take students on the road. Rita revealed that her schools serves a large population of non-traditional students who are older, have been kicked out of their district schools, are a ward of the Department of Juvenile Justice, live in group homes, or are enrolled in military-style boot camps. Rita, who is passionate about the need to serve this particular population, maintained, "Those students are usually here as a last chance." Contrary to Rita's experience and setting, Veronica's students tended to be highly ambitious students busy pursuing other goals and interests during the day, such as dance, theatre, or traveling sports, or who are looking for a platform to accelerate their education with extra classes.

Online teaching and learning also enabled teachers to adapt to student needs and interests through the ability to alter their courses or assignments. Mary supplements her courses with additional options, depending on the students' interest or known software glitches. She explained, "I give them options. If they want to do the one in the course that's fine, but they can go to our message board and choose an option. However, they learn better...here's your other options." Veronica added, "I think that's probably 
the reason that online teaching is near and dear to me, is that I can differentiate. I can give my students options."

Opportunities for design and creativity. In general, the focus group participants were satisfied with the courseware they use to host the materials for their online classes. Just as within the traditional classroom, teachers infused the curriculum with their unique style and interest, and tailored their instruction for the students they teach. Providing teachers with the opportunity to modify existing or design new courses was an inroad to satisfying their expressed need to have input on the curriculum they are delivering. Veronica said:

The other place I have creativity is when I develop or have the opportunity to develop a course, which I'm going to do with this one that's falling apart soon, I will be able to put in the differentiation and I get to find resources, and that's really what I love doing, is development.

Veronica, who in addition to teaching part-time, was also hired to develop online courses for her department, cited course development as one of the most gratifying aspects of her job, and an outlet for her creativity.

\section{Support Network}

Effective leadership is a fundamental element in the operation of any organization, including member retention. Rita professed, "Just like brick and mortar schools, the type of leadership that mentors, encourages, and supports teachers, who communicate a clear vision, is key." Mary cited her school administrators as a primary reason she remains teaching online, stating, "The reason I stay is because my administration is very stable and they're really good people...the administration has your back...that is a huge difference than what I find in the traditional classroom."

Part of good leadership is being able to offer teachers timely support. All participants indicated they were very satisfied with the amount and timeliness of support they received, whether from the administrators, counselors, or technical support staff. The support network extended from the administrative level and is distributed amongst the teachers in the form of collaboration, building a professional community, and mentoring those new to online teaching. When entering the field of education, most of the new teachers were assigned a mentor, or an experienced teacher to help guide them through the school year (AEE, 2005; Green et al., 2009; Smith \& Ingersoll, 2004). Veronica articulated the importance assigning mentors to those new to online teaching:

I think one of the main reasons that we lose teachers in the online environment is lack of training. In my online school, we have a very active teacher quality group that helps train the teachers when they first come on, it provides mentors for the teachers, and it also provides really good professional development that helps make their job easier.

Both Rita and Veronica were strong advocates for professional development and felt like there should be more, particularly for those teachers entering the virtual classroom for the first time. Veronica predicted, "If online schools, as they grow, start to grow so fast that they can't give the teachers that sense of community and that training that they need...I think that will cause our attrition to go up more than anything." 


\section{Discussion}

What is the Level of Job Satisfaction of K-12 Online Teachers?

Overall, K-12 online teachers who participated in the study appear to be satisfied with their jobs. Participants reported a mean satisfaction of 3.69 on a 5-point Likert continuum, indicating a moderate to high level of job satisfaction. The corresponding average total satisfaction score was 103.6 out of 140 possible points, or $74.0 \%$ satisfaction. According to the MSQ satisfaction guidelines, a percentile score of 50 or better was indicative of job satisfaction, while scores above $75 \%$ indicate a high level of job satisfaction. These data are encouraging when compared to recent national study revealing traditional K12 teacher job satisfaction dropped to $44 \%$ while their turnover intentions have increased to $29 \%$ (Markow \& Pieters, 2012).

\section{What is the Level of Organizational Commitment of K-12 Online Teachers?}

Of the three types of organizational commitment, the Affective Commitment scale produced the highest mean score of 23.05 points out of 30, or an average of 3.8 points on a 5-point Likert continuum. This score indicates that participants felt both emotionally and professionally committed to the mission of their organization. When employees possess affective commitment, they desire to see their organization succeed in its goals, and feel a sense of pride for being a member of the organization (Allen \& Meyer, 1990; Cohen, 2003; Meyer, Kam, Gildenberg \& Bremner, 2013; Mowday, Steers \& Porter, 1979; Nagar, 2012; Porter, Crampon \& Smith, 1976; Rusu, 2013a, Rusu 2013b). The results are encouraging for the field K-12 online teaching and learning, as online teacher participants overwhelming exhibited affective commitment to their online school. Employees with a higher degree of emotional commitment are more likely to continue working for the school eagerly and exert considerable effort on behalf of their school, because they feel integrated within the organization and identify with and internalize the norms and values of their school (Nagar, 2012).

The Normative Commitment scale produced a mean score of 20.37 points out of 30 possible points, or an average of 3.39 points on a 5-point Likert continuum, suggesting that participants felt loyal to their organization and likely will not leave due to feelings of obligation or mutual investment. Teachers who displayed normative commitment have a more transactional relationship with their school, but will likely stay employed at their school and put effort into the job because they value the benefits they receive from working at their school. The Continuance commitment scale produced the lowest mean score of 16.75 points out of 30 possible points, or an average of 2.79 points on a 5-point Likert continuum. This data is also encouraging because online teacher participants did not view leaving their school as a cost they cannot afford, indicating that they continued to work for their school because they want to, rather than due to a lack of other options.

\section{What is the Turnover Intention of K-12 Online Teachers?}

When asked if they intended to continue teaching online in the immediate future, $95 \%$ responded Yes, while 5\% responded No. The projected attrition of online teacher participants (19\%) is less than the actual attrition of traditional teachers, which historically ranges from $30 \%$ to $50 \%$ within the first five years of teaching (Ingersoll, Merrill, \& Stuckey, 2014). Additionally, a recent national study of traditional teachers of all experience levels revealed that $29 \%$ of the teachers indicated they plan to leave the classroom permanently (Markow \& Pieters, 2012). The significance of this portion of the study is that the behavioral intentions of teachers are effective predictors of actual behavior; therefore, online teachers' turnover intentions serve as a proxy to actual turnover (Fishbein \& Ajzen, 1975; Hofaidhllaoui \& Chhinzer, 2014). As online school enrollment continues to steadily increase, the participants' intent to remain in the online classroom is a promising projection. 


\section{What do online teachers perceive as barriers or pathways to retention?}

Barriers. Compensation and the lack of income growth potential were the most frequently identified dissatisfying aspect of participant's job. The second most dissatisfying aspect participants identified was students' lack of class participation and motivation, as well as the limited interaction and knowledge the online teachers had of their online students. Participants also identified the general workload of an online teacher as heavy, with demanding turnaround deadlines, large student numbers, and high volumes of data collection and contact logs. Other factors the participants found discouraging or dissatisfying include: the physical demands of a sedentary job, working summers without additional compensation relative to teachers contracted for 10-months, and the quality of available instructional resources. Collectively, data from the quantitative survey, open response questions, and qualitative focus group interviews agree with one another and the data is triangulated.

The analysis of dissatisfying factors in both the Phase I and Phase II data were congruent with previous research studies that revealed a lack of teacher involvement in decision-making processes, lack of administrative support, increased student numbers and workload, inadequate instructional resources, poor compensation, and few opportunities for career advancement among the least satisfying aspects of teaching (Ingersoll, 2001; Page \& Page, 1982; U.S. DOE, 1997). The factors found least satisfying had theoretical underpinnings of Herzberg's Two-Factor Theory. Herzberg et al. (1959) described hygiene items as extrinsic factors that may lead to job dissatisfaction, including pay, job security, growth potential, and interpersonal relationships, all of which were named in some form by study participants. Herzberg notes that the absence of satisfying motivators is not likely to lead to dissatisfaction, rather a state of neutrality, but the presence of dissatisfying hygiene factors will likely create dissatisfaction.

Pathways. Participants reported the convenience and flexibility to teach without regard to time or location as the most satisfying aspect of their job. The second most frequently cited factor was the satisfaction derived from the ability to meet various student needs and populations. Participants were also satisfied with the timeliness and degree of technical support and training they received by their institution. Other aspects of the job that were identified as highly satisfying included: less stress resulting from reduced classroom management and student discipline, building positive student and parent relationships, opportunities to design course content, and a support network that included effective leadership and a professional learning community. Collectively, data from the quantitative survey, open response questions, and qualitative focus group interviews coincided with one another, thus triangulating the data.

The analysis of satisfaction in both Phase I and Phase II also aligned with previous research studies that revealed leadership and support, the formation of positive professional and student relationships, input in the planning and implementation of curriculum, and meeting student needs were chief among the most satisfying aspects of teaching (Bolliger \& Wasilik, 2009; Bolliger et al., 2014; Lortie, 1975; Thompson, 1979; U.S. DOE, 1997). While this study investigated a very modern phenomenon, the aspects identified by participants as most satisfying have undertones of Maslow's (1943, 1954, 1987) higher level needs, including developing close associations with others, gaining prestige in their field, and feelings of accomplishment and personal growth. Further, the findings also support Herzberg et al.'s (1959) assertion that workers are more motivated by intrinsic factors, such as the need for achievement, recognition, responsibility, and the work itself, that will consequently satisfy the worker's need for self-actualization and lead to higher levels of job satisfaction.

\section{Limitations}

Readers should be aware of several limitations as they consider the findings. This research study used a small convenience sample $(\mathrm{n}=108)$ wherein the results from the study were not generalizable beyond this group of online teachers. Another point to consider is that $82 \%$ of participants held a Master's 
degree or higher, and their average teaching experience was 12.54 years, suggesting participants have already determined that teaching is their long-term career path. Traditionally, teacher turnover occurs within the first five years of teaching; however, these teacher participants have already been retained past the critical 5-year point of teacher attrition. Finally, in the satisfaction portion of the online survey, the Institutional Support scale produced the lowest reliability (.51), suggesting that the items included on that scale were not measuring the same concept and thus must be reevaluated for future studies.

\section{Implications for School Leaders Compensation}

Compensation was by far the most frequent complaint of K-12 online teachers. When considering the long-term retention of online teachers, one must also consider a mutual long-term investment. Participants' major concern with their compensation was the lack of income growth potential over the course of their career, as slated, they will be earning the same when they retire, as they were when they were hired. While teachers typically identify intrinsic motivation for entering and remaining in the field of education (Lortie, 1975; Thompson, 1979), compensation is a hygiene item that may create dissatisfaction and consequently teacher turnover (Herzberg et al., 1959). School leaders must also consider the number of online teacher candidates they fail to attract because of stagnant compensation, the lack of compensation for advanced degrees, and limited opportunities for professional growth.

Steady income. In addition to generally lower salaries, online teachers need predictable and steady pay. Most part-time teachers (half of all participants) reported being paid per student, and being paid on a quarterly basis. The challenge with this is the variation in student numbers from semester to semester makes it difficult for teachers to plan and follow a personal budget because while their expenses are fixed, their income is not. Many online teachers find it difficult to meet their financial obligations when they are paid only once or twice a semester and therefore work a second job, which leaves them more susceptible to burnout and turnover.

Summer compensation. Survey participants revealed that most online teachers worked 12month contracts. When considering their pay is already lower than what traditional 10-month teachers receive, the compensatory gap becomes even more exaggerated. Study participants recommended that school leaders move towards a summer school model that is similar to that of traditional schools where teachers may elect to work summers for additional pay, or may choose not to work in the summers. However, if required to fulfill a 12-month contract, online teachers are adamant that these two additional months should be reflected in their already reduced salaries.

\section{Design Opportunities}

The survey's open response questions and the focus group discussions revealed that K-12 online teachers value opportunities to influence the design of courseware. Some participants, who are involved in designing new courses or redesigning older courses, affirmed that course design was the most enjoyable aspect of their job. Providing teachers with the opportunity to influence the curriculum they are delivering supports teachers' desire to maintain their professional identity while infusing their individual creativity into the curriculum, thereby creating a sense of ownership of the courseware.

\section{Face-to-Face Opportunities}

One of the factors ranked most satisfying among K-12 online teachers is the opportunity to collaborate and work in a professional community of educators, and to build positive relationships with students and parents; contrariwise, one of the factors ranked as most dissatisfying was missing meaningful interactions with students. Jointly, these factors illustrate the value educators place on the learning community and feelings of connectedness. Presently there are various school models, some allowing regular, few, or no face-to-face interaction with students and other online educators. Striking a 
balance between opportunities for teachers and students to meet face-to-face may prove valuable to online school leaders as they consider the needs and satisfaction of their online teachers.

\section{Recommendations for Future Research}

Participants of this study encouraged K-12 online school leaders to assign a mentor to new hires; however, this study does not clarify which mentoring model will have the greatest effect on teacher retention. While 78 of 108 study participants reported they received a mentor and gave some indication as to the frequency of their meeting, the researchers do not know what the mentoring entailed, or how this varied from school to school. Future research should investigate specific models, frequencies, durations, and mediums of mentorship in the K-12 online environment to support school leaders and mentors in designing mentorship programs that positively effect online teaching practices and student learning outcomes.

School governance type proved to be another ambiguous component of the survey. Due to the wide variety and compound nature of online school types, participants were allowed to select more than one type of online school model. For example, a school might be a district and a charter school, a district school that is affiliated with the state, or a for-profit charter school. The multiple response option resulted in 23 unique school combinations and a total number of data points that exceeded the number of participants. This makes school model a difficult variable to analyze with regard to satisfaction, commitment, and turnover intention. For future studies, it is recommended that concrete school governance and funding types should be set to a single-option response on surveys. This will enable researchers to draw meaningful conclusions about the practices of specific school models, as well as compare the levels of teacher satisfaction, commitment, and turnover by school model. The information assembled from this analysis could help researchers identify best practices that lead to higher levels of K12 online teacher retention.

It is recommended that the JSCOT survey instrument be further refined, with particular regard to the Institutional Support satisfaction scale. The questions on this scale must be aligned or subdivided into a separate scale to include compensation, benefits, and return on investment. After adjusting the Institutional Support scale, the instrument should be implemented with a larger sample. This study evaluated the experiences and perceptions of 108 online teachers within a single Southeastern state, and while some clear themes emerged from the survey and focus group analysis, this is a small sample size relative to the number of K-12 online teachers throughout the United States.

Finally, at present researchers can only measure turnover intentions but do not have longitudinal trend data for actual K-12 online teacher attrition. It would be worth comparing the attrition of online teachers, particularly those brand new to teaching, in relation to traditional teacher attrition, which generally ranges from $30-50 \%$ within the first five years of employment. Presently, the turnover intentions of K-12 online teachers is lower than that of traditional teachers, with only $19 \%$ projecting they will leave the online classroom within the next five years, but as previously stated, this must be considered critically because the average participant surveyed is already past their fifth year of teaching. 


\section{References}

Allen, N. J., \& Meyer, J. P. (1990) The measurement and antecedents of affective, continuance and normative commitment. Journal of Occupational Psychology, 63(1), 1-18.

Allen, I. E., \& Seaman, J. (2013). Staying the course: Ten years of tracking online education in the United States. Needham, MA: The Sloan Consortium.

Alliance for Excellent Education (AEE). (2014). On the path to equity: Improving the effectiveness of beginning teachers. Retrieved from http://all4ed.org/wpcontent/uploads/2014/07/PathToEquity.pdf

Archambault, L., \& Crippen, K. (2009). K-12 distance educators at work: Who's teaching online across the United States. Journal of Research on Technology in Education, 41(4), 363-391.

Barbour, M. K. (2012). Models and resources for online teacher preparation and mentoring. In K. M. Kennedy \& L. Archambault (Eds.), Lessons learned in teacher mentoring: Supporting educators in K-12 online learning environments (pp. 83-102). Vienna, VA: International Association for K12 Online Learning.

Blackburn, R. T., \& Lawrence, J. H. (1995). Faculty at work: Motivation, expectation, satisfaction. Baltimore, MD: Johns Hopkins University Press.

Bluedorn, A. C. (1982). A unified model of turnover from organizations. Human Relations, 35 (2), 135 153.

Bolliger, D. U., Inan, F. A., \& Wasilik, O. (2014). Development and validation of the online instructor satisfaction measure (OISM). Journal of Educational Technology \& Society, 17(2), 183-195. Retrieved from http://www.ifets.info/journals/17 2/15.pdf

Bolliger, D. U., \& Wasilik, O. (2009). Factors influencing faculty satisfaction with online teaching and learning in higher education. Distance Education, 30(1), 103-116.

Chaney, T. G. (1991). Job satisfaction, organizational commitment, and intent to stay among United States Air Force certified registered nurse anesthetists. Unpublished master's thesis. State University of New York.

Chacon, F., Vecina, M. L., \& Davila, M. C. (2007). The three-stage model of volunteers' duration of service. Social Behavior and Personality, 35,627-642.

Cohen, A. (2003). Multiple commitments in the workplace. Mahwah, NJ: Lawrence Erlbaum.

Creswell, J. W. (2009). Research design: Qualitative, quantitative, and mixed methods approaches ( $3^{\text {rd }}$ ed.). Thousand Oaks, CA: Sage.

Cronbach, L. J. (1951). Coefficient alpha and the internal structure of tests. Psychometrika, 16(3), 297332. 
Dalessio, A., Silverman, W. H., \& Schuck, J. R. (1986). Paths to turnover: a re-analysis and review of existing data on the Mobley, Horner and Hollingsworth Turnover Model. Human Relations, $39(3), 264-70$.

Darling-Hammond, L. (2001). The challenge of staffing our schools. Educational Leadership, 58(8), 1217.

Dawson, T. A. (2001). Filling the gap: Can better recruitment, orientation, and benefits programs help beat the teacher shortage? New York, NY: Teachers Insurance and Annuity Association College Retirement Equities Fund (TIAA-CREF).

Deubel, P. (2008). K-12 online teaching endorsements: Are they needed? T.H.E. Journal. Retrieved from http://thejournal.com/articles/2008/01/10/k12-online-teaching-endorsements-are-theyneeded.aspx

Ewing, R., \& Manuel, J. (2005). Retaining early career teachers in the profession: New teacher narratives. Change: Transformations in Education, 8(1), 1-16.

Fishbein, M., \& Ajzen, I. (1975). Belief, attitude, intention and behavior: An introduction to theory and research. Reading, MA: Addison-Wesley.

Fournier, R. (2013). K12 online teachers: Where is the preparation? EdTech Times. Retrieved from http://edtechtimes.com/2013/07/17/k-12-online-teachers-where-is-the-preparation/.

Gemin, B., Pape, L., Vashaw, L., \& Watson, J. (2015). Keeping pace with K-12 online learning. Retrieved from Evergreen Education Group website: http://www.kpk12.com/wpcontent/uploads/Evergreen_KeepingPace 2015.pdf

Green, T., Alejandro, J., \& Brown, A. (2009). The retention of experienced faculty in online distance education programs: Understanding factors that impact their involvement. The International Review of Research in Open and Distance Learning, 10(3). Retrieved from http://www.irrodl.org/index.php/irrodl/article/view/683/1279

Hagedorn, L. S. (2000). What contributes to job satisfaction among faculty and staff: New directions for institutional research. San Francisco, CA: Jossey-Bass.

Herzberg, F. (1968). Work and the nature of man. Cleveland, OH: World Publishing.

Herzberg, F., Mausner, B., \& Snyderman, B. B. (1959). The motivation to work. New York, NY: John Wiley \& Sons.

Hewitt Associates. (2004). Strategies for cost management of the HR function. Timely Topics. Retrieved from http://hrledger.com/library/HR_Costs_Hewitt_2004.pdf

Hofaidhllaoui, M., \& Chhinzer, N. (2014). The relationship between satisfaction and turnover intentions for knowledge workers. Engineering Management Journal, 26(2), 3-9.

Igbaria, M., \& Greenhaus, J. (1992). Determinants of MIS employees' turnover intentions: A structural equation model. Communications of the ACM, 35(2), 34-49. 
Ingersoll, R. M. (2001). Teacher turnover and teacher shortages: An organizational analysis. American Educational Research Journal, 38(3), 499-534.

Ingersoll, R. M. (2002) Holes in the teacher supply bucket. The School Administrator, 59(3). 499-534.

Ingersoll, R., Merrill, L., \& Stuckey, D. (2014). Seven trends: The transformation of the teaching force. CPRE Research Report \# RR-80. Philadelphia, PA: Consortium for Policy Research in Education. http://www.cpre.org/sites/default/files/workingpapers/1506 7trendsapril2014.pdf

Johnson, R. B., Onwuegbuzie, A. J., \& Turner, L.A. (2007). Toward a definition of mixed methods research. Journal of Mixed Methods Research, 1(2), 112-133.

Larkin, I. M. (2015). Job satisfaction, organizational commitment, and turnover intention of online teachers in the K-12 setting (Doctoral dissertation). Retrieved from http://digitalcommons.kennesaw.edu/cgi/viewcontent.cgi?article $=1003 \&$ context=instruceddoc et d

Lee, T. W., \& Mowday, R. T. (1987). Voluntarily leaving an organization: An empirical investigation of Steers and Mowday's model of turnover. Academy of Management Journal, 30(4), 721-743.

Lortie, D. C. (1975). Schoolteacher: A sociological study. Chicago, IL: University of Chicago Press.

Markow, D., \& Pieters, A. (2012). MetLife survey of teacher education - Teachers, parents and the economy. Retrieved https://www.metlife.com/assets/cao/foundation/MetLife-Teacher-Survey2011.pdf

Maslow, A. H. (1943). A theory of human motivation. Psychological Review, 50(4), 370-396.

Maslow, A. H. (1954). Motivation and personality. New York: Harper \& Brothers. Wiley \& Sons.

Maslow, A. H. (1987). Motivation and personality (3rd ed.). New York, NY: Harper \& Row.

Mathieu, J., \& Zajac, D. (1990). A review and meta-analysis of the antecedents, correlates, and consequences of organizational commitment. Psychological Bulletin, 108(2), 171-194.

McLawhon, R., \& Cutright, M. (2011). Instructor learning styles as indicators of online faculty satisfaction. Educational Technology \& Society, 15(2), 341-353.

Merriam, S. B. (2009). Qualitative research: A guide to design and implementation. San Francisco, CA: Jossey-Bass.

Meyer, J. P., \& Allen, N. J. (1991). A three-component conceptualization of organizational commitment. Human Resources Management, 1(1), 61-89.

Meyer, J. P., \& Allen, N. (1997). Commitment in the workplace. Thousand Oaks, CA: Sage.

Meyer, P. J., Allen, J. N., \& Smith, C. A. (1993). Commitment to organizations and occupations: Extension and test of a three-component conceptualization. Journal of Applied Psychology, 78(4), 538-551. 
Meyer, J. P., Kam, C., Gildenberg, I., \& Bremner, N. L. (2013). Organizational commitment in the military: Application of a profile approach. Military Psychology, 25(4), 381-401.

Mowday, R. T., Steers, R. M., \& Porter, L. W. (1979). The measurement of organizational commitment. Journal of Vocational Behavior, 14(2), 224 - 247.

Mowday, R. T., Porter, L. M., \& Steers, R. M. (1982). Employee-organization linkables: The psychology of commitment, absenteeism, and turnover. New York, NY: Academic Press.

Nagar, K. (2012). Organizational commitment and job satisfaction among teachers during times of burnout. Research Journal, 37(2), 43-60.

Page F. M. Jr., \& Page J. A. (1982). Perceptions of teaching that may be influencing the current shortage of teachers. College Student Journal, 16, 308-311.

Perrachione, B. A., Petersen, G. J., \& Rosser, V. J. (2008). Why do they stay? Elementary teachers' perceptions of job satisfaction and retention. Professional Educator, 32(2), 25-41.

Picciano, A., Seaman, J., \& Allen, I. (2010). Educational transformation through online learning: To be or not to be. Journal of Asynchronous Learning Networks, 14(4), 17- 35.

Porter, L. W., Crampon, W. J., \& Smith, F. L. (1976). Organizational commitment and managerial turnover. Organizational Behavior and Human Performance, 15(1), 87-98.

Riley, R. W. (1999). New challenges, a new resolve: Moving American education into the 21st century. Speech presented at the sixth annual State of American Education, Long Beach, CA.

Rusu, R. (2013a). Affective organizational commitment, continuance organizational commitment or normative organizational commitment? Buletin Stiintific, 18(2), 192-197.

Rusu, R. (2013b). Organization commitment - From its beginnings until today. Buletin Stiintific, 18(2), 181-186.

Saldana, J. (2013). The coding manual for qualitative researchers (2nd ed.). Thousand Oaks, CA: Sage.

Sirin, H., \& Sirin, E. F. (2013). Research on the organizational commitment of the instructors in terms of job satisfaction, and organizational alienation: School of physical education and sports sample. International Journal of Academic Research, 5(3), 176-183.

Tett, R. P., \& Meyer, J. P. (1993). Job satisfaction, organizational commitment, turnover intention, and turnover: Path analyses based on meta-analytic findings. Personnel Psychology, 46(2), 259-293.

Thompson, S. (1979). Motivation of teachers. ACSA school management digest, series 1, number 18. ERIC CEM research analysis series, number 46. Washington, DC: ERIC Clearinghouse. Retrieved from http://files.eric.ed.gov/fulltext/ED178998.pdf

U.S. Department of Education, National Center for Education Statistics. (1997). Job satisfaction among America's teachers: effects of workplace conditions, background characteristics, and teacher compensation. US Department of Education, Washington, DC. Retrieved from http://nces.ed.gov/pubs/ce/c9749a01.html. 
Van Dick, R. (2001). Identification in organizational contexts: Linking theory and research from social and organizational psychology. International Journal of Management Reviews, 3(4), 265-283.

Vandenberg R. J., \& Nelson J. B. (1999) Disaggregating the motives underlying turnover intentions: When do intentions predict turnover behaviour? Human Relations, 52, 1313-1336.

Vogt, W. P. (2007). Quantitative research methods for professionals. Boston, MA: Pearson Education, Inc.

Vroom, V. H. (1964). Work and motivation. New York, NY: Wiley.

Watson, J., Pape, L., Murin, A., Gemin, B., \& Vashaw, L. (2014). Keeping pace with K-12 online learning. Retrieved from Evergreen Education Group website: http://www.kpk12.com/wpcontent/uploads/EEG_KP2014-fnl-lr.pdf

Watson T. (2010). Leader ethics and organizational commitment. Undergraduate Leadership Review, $3(1), 16-26$.

Wiener, Y. (1982). Commitment in organizations: A normative view. Academy of Management Review, 7, 418-428.

Weiner, Y., \& Gechman, A.S. (1977). Commitment: A behavioral approach to job involvement. Journal of Vocational Behavior, 10, 47-52.

Weiss, D. J., Dawis, R. V., Lofquist, L. H., \& England, G. W. (1966). Manual for the Minnesota satisfaction questionnaire. Minnesota studies in vocational rehabilitation, 21. Industrial Relation Center, Minneapolis, MN: University of Minnesota.

Weiss, D.J., Dawis, R.V., England, G.W., \& Lofquist, L.H. (1967). Manual for the Minnesota satisfaction questionnaire. Minnesota studies in vocational rehabilitation, 22. Industrial Relation Center, Minneapolis, MN: University of Minnesota. 